\title{
Climate Change: Impacts on the Production of Cotton in Pakistan
}

\author{
A. L. Siyal, T. G. Mahesar, F. Sufyan, F.K. Siyal, T. Jatt, F. H. Mangi, \\ N. Shaikh, I. H. Burdi, and A Hossain
}

\section{ABSTRACT}

Climatic changes seriously threaten Agriculture globally year to year, especially in developing countries like Pakistan. Agricultural productivity directly influenced by Climatic factor i.e., increase in high temperature, heavy rainwater, precipitation, flood and deficiency of irrigation etc. Climate patterns reduce global temperatures by 2.9 to 5.5 degrees Celsius by 2060, and crop yields are at high risk of these trends. Extreme temperatures negatively regulate crop phenology, leading to significant reductions in crop yields. Temperatures and changes in the rainy season affect the cotton growth and make threats the stability of cotton production and quality in Pakistan. Cultivation of Cotton is especially targeted on its thread, but its oil extensively uses as an incoming vegetable oil and make an essential contribution to the oil industry across the country. Pakistani farmers survey and prepare to get quality fiber and lint yield, Pakistan also meets 18.8 percent demands of oil from cotton seeds. Additionally, there is strong need from industry to strengthen cotton oil so it can be used directly as vegetable cooking oil. This research provides approaching into the climatic conditions of Pakistan and their effect on the production of better cotton.

Keywords: Climate change, Cotton production, Global warming.
Submitted: May 27, 2021

Published: June 30,2021

ISSN: $2684-1827$

DOI: 10.24018 /ejfood.2021.3.3.306

\section{A. L. Siyal*}

Sindh Agriculture University, Tandojam, Sindh, Pakistan.

Sustainable Agriculture Farmers Welfare Organization, Sindh, Pakistan.

(e-mail: latifayazsiyal@ ${ }^{@}$ gmail.com)

T. G. Mahesar

World Wild Fund for Nature (WWF), Pakistan.

(e-mail: tgmahesar@wwf.org.pk)

F. Sufyan

World Wild Fund for Nature (WWF),

Pakistan.

(e-mail: fsufyan@wwf.org.pk)

F. K. Siyal

Department of Botany, Shah Abdul

Latif University, Khairpur, Pakistan.

(e-mail: f.asad.siyal@salu.edu.pk)

T. Jatt

Department of Botany, Shah Abdul

Latif University, Khairpur, Pakistan.

(e-mail: tahirajatt ${ }^{@}$ gmail.com)

F. H. Mangi

World Wild Fund for Nature (WWF),

Pakistan.

(e-mail: fhmangi@wwf.org.pk)

I. H. Burdi

Sustainable Agriculture Farmers

Welfare Organization, Sindh, Pakistan.

(e-mail: imtiaz_burdi@yahoo.com)

A. Hossain

Department of Agronomy, Wheat and

Maize Research Institute, Dinajpur,

Bangladesh.

(e-mail: akbarhossainwrc@gmail.com)

*Corresponding Author

\section{INTRODUCTION}

Cotton is kharif season and important fiber cash crop and it contributes a pivotal role in agricultural and industrial economy of Pakistan. It is water thirsty crop and for the cultivation of crop 6 percent of water irrigation can be used. In Pakistan cotton grown on a large scale of area in Sindh, Punjab, and Balochistan. Punjab is the largest producer of cotton followed by Sindh and Balochistan. It is very well may be grown on a wide range of soil having $\mathrm{pH}$ levels in-between 6-8. Profound, friable, well irrigated, and fertile soil is useful for crop cultivation. Sandy, saline, or waterlogged soils are not appropriate for cultivation of cotton crop. The depth of soil ought not be under 20-25 cm. Harvest assurance expanded with expansion in the utilization of engineered synthetic substances and composts in cotton harvest and result in generally speaking expansion in yield of cotton crop. Cotton is a major crop after wheat, in term to area-covered 
crop [1]. Cotton is a wordlist top fiber amid usual crop extends only worlds' prevalent textile industry have an annually fiscal impact of as a minimum $\$ 600$ billion global [2]. Cotton cultivation is fundamentally centered on its thread yet cotton oil be essentially utilized while a food vegetable oil and causes most important to supply in the public oil manufacturing [3]. In Asia, Pakistan is the third-largest spinning capacity limit and likewise the fourth-largest producer of cotton and the $7^{\text {th }}$ largest cloth manufacturer in the world. About 60 percent of Pakistan's foreign income comes from cotton products [4] However, at least $2 \%$ of Pakistan's (GDP) economy is dependent entirely on cotton and its derivatives, and its value is included in agricultural areas [5]. Pakistan's agricultural sector is highly sensitive to climate change and there is a high risk of unpredictable weather conditions in cotton-growing belts [6].

\section{IMPORTANCE OF COTTON PRODUCTION IN PAKISTAN}

Pakistan's cotton production for the 2019/20 marketing year is forecast to be 8.0 million four hundred eighty pounds bales of cotton, with an estimated five hundred thousand bales for 2018to 2019.Cotton being a cash crop and an essential source of raw material to the textile, enables the textile industry to survive and expand its base. The cotton has share of 1.0 percent in GDP and contributes 5.1 percent in agriculture value addition. The government is focusing on supporting small and marginalized farmers and promotes small scale innovative technologies to promote growth in this sector. Based on the availability of sufficient water and certified seeds, cotton production is expected to grow more than last year. 95 percent of cotton of Pakistan is bioengineered. Textile mill utilization is estimated to be a little higher at 10.7 million bales as require for products of cotton has increased with the help of the government for textile exports. To meet the demand for all mills' products, a higher price of fabric is offered, with imports of 3.0 million $480 \mathrm{lb}$ bales imported. According to the advanced BT and seed narrow framework, investment and performance will assist the beginning of better cotton seed. Cotton is the major income increasing crop of Pakistan's textile business. From April to June, cotton is cultivated on $15 \%$ of cultivable crops during the 'Kharif' or tempest season. Creation is amassed in two regions with comprised about $75 \%$ and Sindh about $25 \%$ of region. Typically, cotton is grown on five hectares of land from today's farmer, predictable 1.6 million growers produce cotton. Textile is an essential industrial division of country and employs 40 percent records of the industrial manpower and 10 million employees. The region generates an additional of $8 \%$ of GDP and more than $50 \%$ of foreign agricultural profits, which is the largest share of several extra item for consumption. The combined cotton as well as textile area including 1,050 ginneries, 430 textile industry, and cotton seed purifiers and oil refiners.

Pakistan's cotton production in August/July 2019/20 is predictable by 8.0 million $480 \mathrm{lb}$ bales 10.2 million $170 \mathrm{~kg}$ bales or 1.74 million metric tons. The reason for a farmers' plant decision is due to factors other than estimated rates, such as the cost of challenging crops, availability of produce, and the cost of government-assisted production. Cotton area is expected to grow to 2.5 million hectares this time because of strong cotton price globally and low governmental hold up to buy seeds and minimum support prices, hopefully some famers will get cotton. The purchase price and minimum support price for the new plowing fields are predictable to promote some grower to move up production of cotton. Cotton cultivation is estimated from March in Sindh and in April in the Punjab's largest produce province. State official have banned the growing since April 1, 2019. The purpose of this strategy is to combat the time of injury-moth action in cotton-growing locations. Cotton production is anticipated to improve primarily based on availability of better water and licensed seeds to the agricultural community. Based on heavy precipitation and intense snowstorm at some point of February to March, water availability for summertime crops is anticipated to remain regular. Government has procured huge quantities of licensed bio-engineered seeds of the most modern varieties of cotton, on the way to enhance farmers' choice to grow better crops. The Punjab regional authorities have announced they will provide free, certified seeds on one lac acres enhancing over the preceding time. Once apply to the Department of Agriculture farmers will get seeds on 1 to 2 acres through balloting whereas, planning for sensible of fertilizer and pesticides supply is under the process.MY 2019 to 20 projected years at $697 \mathrm{~kg}$ per hectare, $3 \%$ superior more than this year's estimation of $680 \mathrm{~kg} /$ hectare. There are some positive and negative factors that affect yields. In 2020-21, Pakistan is still the fifth largest cotton producer of cotton in the world, but the gap with the top four producers in widening. In fact, in the current marketing season, Pakistan's cotton production will be only two and a half times that of Brazil, just three seasons ago, when two countries were tied for the fourth position.

TABLE I: DATA OF AREA, COTTON BALLS, LINT PRODUCTION AND LINT YIELD OF COTTON CROP IN PAKISTAN (2014-2020)

\begin{tabular}{ccccc}
\hline Year & $\begin{array}{c}\text { Area (million } \\
\text { hectares) }\end{array}$ & Cotton balls & Lint production & $\begin{array}{c}\text { Lint } \\
\text { yield }\end{array}$ \\
\hline $2014-15$ & 2.78 & 9.3 & 1.48 & 810 \\
$2015-16$ & 2.53 & 9.0 & 1.53 & 587 \\
$2016-17$ & 2.49 & 7.6 & 1.67 & 730 \\
$2017-18$ & 2.69 & 11.8 & 1.93 & 752 \\
$2018-19$ & 2.74 & 10.4 & 1.87 & 678 \\
$2019-20$ & 2.52 & 10.2 & 1.80 & 670 \\
\hline
\end{tabular}

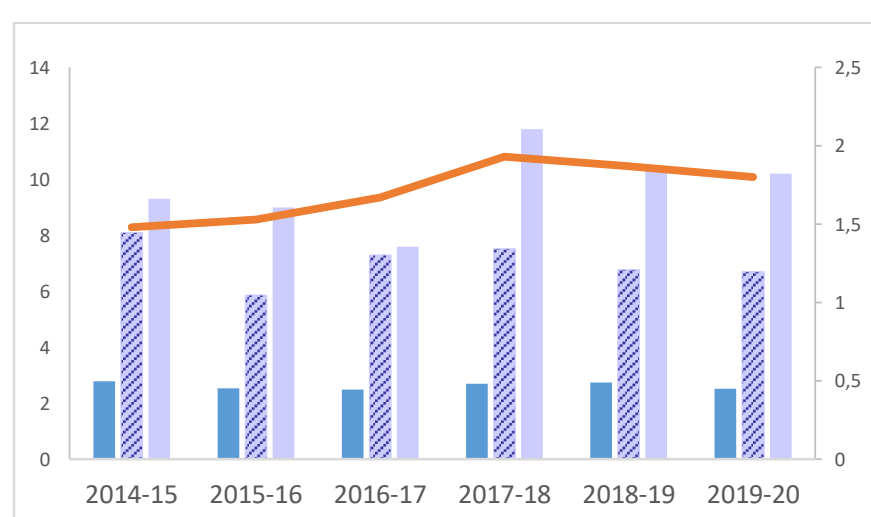

Area (million hectares) $\% / \%$ Lint yield $\quad$ Cotton balls $\longrightarrow$ Lint production

Fig.1.Cotton production in Pakistan (2014-2020) 


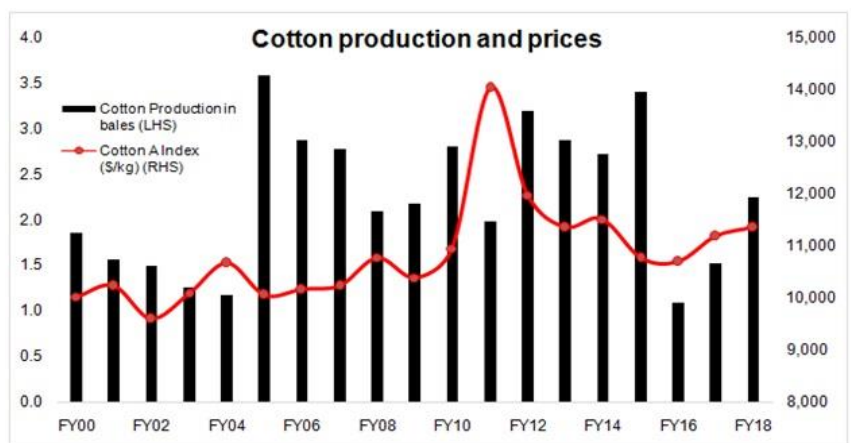

Fig. 2. Cotton production and Prices.

\section{TEMPERATURE CHANGES AND COTTON YIELD}

Cotton is the mainly fiber-rich crop grown worldwide. Scientists have begun to believe the effects of climatic conditions on the production of cotton. Researchers from different regions are exploring the use of statistical method along with the models of crop and climate models of region. The Intergovernmental Panel on Climate Change (IPCC) special report (SR) on stay below $1.5{ }^{\circ} \mathrm{C}$ mentioned that there is extremely high assurance in biological reactions to present climatic change, for the most part rising temperature [7], based on further evidence from a wider series of species [8]. Increases in temperature and shift in the rainfall cycle affect cotton growth development [9] and threaten the permanence of cotton production and quality in Pakistan. Extreme weather events (EWEs) are causing 50\% of yield reductions in agronomic crops globally [10]. During the late developmental stages, high temperatures can cause flower buds to grow. The retention of Boll is highly desirable for high crop values, while the high temperature during this stage severely affects the retention of Boll, as opposed to any other factor, because high temperatures also cause a change in the size (size of the bowl) and a period of maturity [11]. There is generous information announcing extreme yield decrease under heat pressure during late conceptive phases of blossoming and boll arrangement, consequently connoting the blooming stage as generally basic to warm pressure [12]. The main climatic variables affecting cotton during the flowering stage at most sites were relative air humidity and temperature, for cotton seed yield were sunshine duration, and average, maximum, and minimum temperatures. Lint percentage was mainly affected by precipitation, sunshine duration, and average temperature. All together the increase in temperature and precipitation decreases the production agricultural crops annually [13]. Increase in temperature up to a positive level increases the production of rice. Unexpectedly, rise in precipitation does not harm the rice production. In case the production of Cotton, changes in climatic conditions have negative impact. Sugarcane production is also negative affects by increase in temperature [14]. Cultivated produce is affected by climate change in all the four provinces of Pakistan. Low yields are expected in arid area, posing a major threat to food security. [15]. In Pakistan production of Cotton crop is directly related to meteorological environment. warmth and rainfall risen, over last fifty years, and incredible trial take place normally [16]. Consequently, the impact of climatic conditions on the production of cotton in various locations assessed so as to inform the usable climatic resources in production of cotton in diverse location as well as growing structures, production recommend management and technological testing, and encourage adaption and sustainable growth in cotton production. Additionally, for seed of cotton production and percentage of lint (yield indicators), the growing elevation and weight are significant in economically viable conditions. Noteworthy positive collaboration amid cotton seed production and height of plant began, Earlier, Pakistan's Kharif crops suffered major monsoon floods from July to September 2010. This was a time when Pakistan was shutting down an average annual production 5 to 13 million bales a year. It was not long before a decline in Pakistan's crop led India to impose a ban on cotton export, pushing international cotton prices into an upward spiral, rising to 2.25 per $\mathrm{kg}$. A further 18 million was sent before coming down the psychological barrier. Fast forward to 2020, and the world could look no different. When the global lockdown began in April 2020, cotton prices fell to an 11-year low of $\$ 1.40$ per $\mathrm{kg}$, leading to fears of a sharp drop in supply from beginning of the next marketing year, August 2020 to July 2021. The stock ended up accounting for more than 80 percent of production, down slightly from 40 percent in the 2011 , flood year.

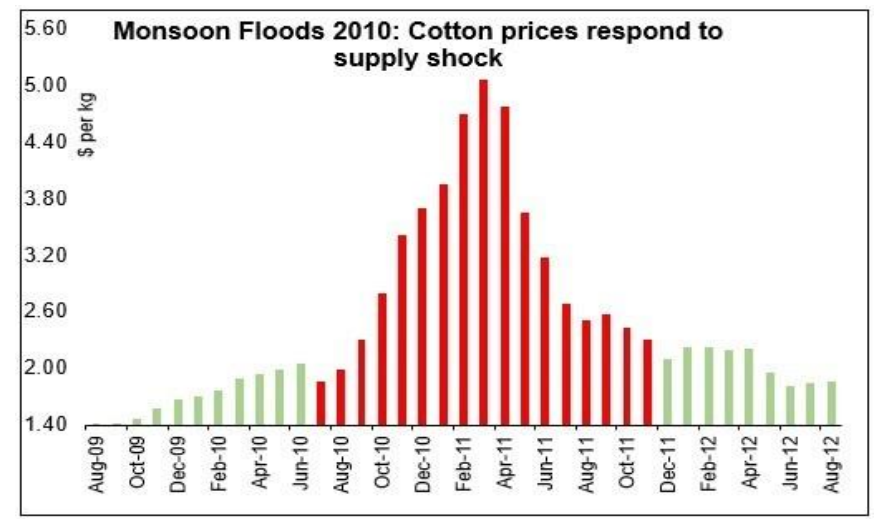

Fig. 3. Downfall in the production and prices in Pakistan (2010-2020).

\section{ACKNOWLEDGMENT}

The Author sincerely appreciate WorldWild Fund for Nature Pakistan (WWF) for their and contributions and funding for this research work.

\section{REFERENCES}

[1] Ali and O. Erenstein, Assessing farmer use of climate change adaptation practices and impacts on food security and poverty in Pakistan. Clim. Risk Manag, 16: (2017) 183-194.

[2] Rehman, L. Jingdong, A. A. Chandio, I. Hussain, S. A. Wagan and Q. U. A. Memon, Economic perspectives of cotton crop in Pakistan: A time series analysis (1970-2015) (Part 1). J. Saudi Soc. Agric. Sci, 18, (2019) 49-54.

[3] J. Ashraf, D. Zuo, Q. Wang, W. Malik, Y. Zhang, M. A. Abid and G. Song, Recent insights into cotton functional genomics: progress and future perspectives. Plant Biotechnol. 16(3): (2018) 699-713.

[4] F. Shuli, A. H. Jarwar, X. Wang, L. Wang and Q. Ma, Overview of the cotton in Pakistan and its future prospects. Pak. Journal of Agricultural Research, 31(4): (2018) 396-407.

[5] K. B. Sial, A. D. Kalhoro, M. Z. Ahsan, M. S. Mojidano, A. W. Soomro, R. Q. Hashmi and A. Keerio, Performance of different upland cotton varieties under the climatic condition of central zone of Sindh. American-Eurasian J. Agric. Environ. Sci, 14: (2014) 1447-1449.

[6] A. Bakhsh, A. Q. Rao, A. A. Shahid, T. Husnain and S. Riazuddin, Insect resistance and risk assessment studies in advance line of Bt. Cotton harboring Cry 1AC and Cry 2A genes (2009). 
[7] J. Rogelj, D. Shindell, K. Jiang, S. Fifita, P. Forster, V. Ginzburg, C. Handa, H. Kheshgi, S. Kobayashi and E. Kriegler, Mitigation Pathways Compatible with $1.5{ }^{\circ} \mathrm{C}$ in the Context of Sustainable Development. IPCC SR1. 5. (2018).

[8] F. Zulfiqar, A. Datta and G. B. Thapa, Determinants and resource use efficiency of "better cotton": An innovative cleaner production alternative. J. Clean. Prod, 166, (2017) 1372-1380.

[9] S. Ahmad, Q. Abbas, G. Abbas, Z. Fatima, S. Naz, H. Younis, R. Khan, W. Nasim, M. Habib ur Rehman and A. Ahmad, Quantification of Climate Warming and Crop Management Impacts on Cotton Phenology. Plants, (2017) 6, 7.

[10] P. Ton, Cotton and climate change: Impacts and options to mitigate and adapt, Geneva, Switzerland: Int. Trade center (2011).

[11] D. Oosterhuis, Day or night high temperature: A major cause of yield variability. Cotton grower, 46 (9): (2002) 8-9.

[12] T. L. Delworth, A. Rosati, W. Anderson, A. J. Adcroft, V. Balaji, R. Benson, K. Dixon, S. M. Griffies, H. C. Lee, R. C. Pacanowski, G. A. Vecchi, A. T. Wittenberg, F. Zeng and R. Zhang, Simulated climate and climate change in the GFDL CM2. 5 high-resolution coupled climate model. J. Clim, 25(8): (2012) 2755-2781.

[13] M. Ahmed and M. Schmitz Economic assessment of the impact of climate change on the agriculture of Pakistan. Business and Economic Horizons, 4, (2011) 1-12.

[14] U. Shakoor, M. Rashid, A. Saboor, N. Khurshid, Z. Husnain and A. Rehman, Maize production response to climate change in Pakistan: A time series assessment. Sarhad J. Agric. 33(2): (2017) 320-330.

[15] Y. Li and C. Sun, Impacts of superimposed climate trends on droughts over 1961-2013 in Xinjiang, China. Theor. Appl. Climatol. 129, (2017) 1-18.

[16] A. K. Muhammad, A. W. Baloch, J. K. Sootaher, N. Gandahi, M. S Chang, G. F. K. Khail, A. Jadgal, A. L. Siyal, A. Maree and U. A. Kasi, Assessment of genetic divergence and character association in upland cotton (gossypiumhirsutuml.) Genotypes. Int. J. Biol. Biotech., 18 (2): (2021) 321-327.

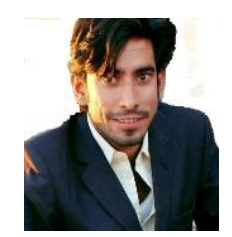

Ayaz Latif Siyal was born in Pacca Chang, District Khairpur Mir's Sindh Pakistan on $10^{\text {th }}$ of July 1993. Mr. Siyalobtained a master's degree in Plant Breeding and Genetics from Sindh Agriculture University, Tandojam, Pakistan. He acquired extensive experience at different designations in various leading organizations (such as, Research and Development Foundation and Sustainable Agriculture Farmers Welfare Organization). He has a wide experience in field research and produced a number of research articles in his career. His research interests are discovery and evaluate new varieties of Wheat (Triticum aestivum L.) for Human consumption. It is worth mentioning here that he is author of a book "Gateway to Plant Breeding" and furthermore he has more than ten research articles in research journals of international repute to his credit. He participated and presented research papers in international conferences and workshops.

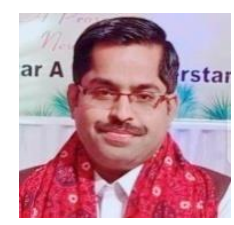

Mr. Toheed Ghani Mahesar is from Sukkur, Sindh He has done his master's in agriculture from Sindh Agriculture University, Tandojam in 2007. He started his career in 2007 from Agri. Banking and has been associated with different organizations with focus on improving farmers' livelihood, efficient natural resource management, water management in the agriculture, particularly in cotton crop, networking and greening the cotton supply chain. He is also accredited trainer of Better Cotton Initiative (BCI). Currently, he is working as program manager at WWF- Pakistan office in Sukkur, Sindh.

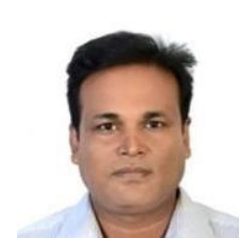

Dr. Akbar Hossain is presently working as a senior agronomist at the Bangladesh Wheat and Maize Research Institute. Dr. Hossain finished his Ph. D degree from the Institute of Ecology and Biological Sciences (particularly stress physiology), Astrakhan State University, Russia. The research interests and expertise of Dr. Hossain including plant physiology, conventional and molecular breeding, biotechnology, genetic engineering, crop and weed management, weed biology and ecology, conservation agriculture, climate change impact assessment on field crops through modeling. He has authored more than 200 journal articles and is currently serving as an MS student supervisor and also a voluntary reviewer/editor for different journals. Dr. Hossain is also linked with several international projects.

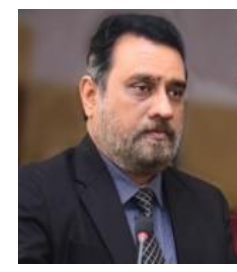

Dr. Nasiruddin Shaikh is working as a Professor in Department of Botany, Govt. College University Hyderabad. He did Ph.D. in Molecular Physiology from Robert Hill Institute at University of Sheffield U.K. Dr. Shaikh is a dedicated researcher and education specialist working on various high profile assignments in different public institutions connected with the field of Education.

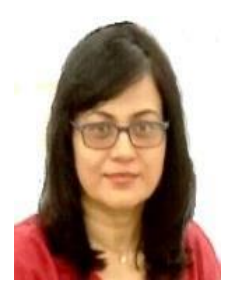

Dr. Tahira Jatt born in Sakrand town District SBA Sindh Pakistan on $12^{\text {th }}$ of August 1995. She did Ph.D. in Cytogenetics. Dr. Jatt is working as an Assistant Professor in Shah Abdul Latif University Khairpur Sindh Pakistan. She is skilled in Cytogenetics techniques and Crop Sciences. She has published her research in peer reviewed journal.

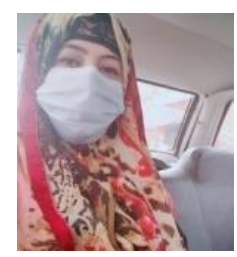

Fozia Khan Siyal born on $5^{\text {th }}$ July 1973 at Moro Sindh. She got her master's degree in Botany and M.Phil. in Marine Sciences from University of Sindh. She achieved Chinese scholarship for PhD. Studies in 2010. Currently, she is working as Professor at Shah Abdul Latif University Khairpur Mir's Sindh, Pakistan.

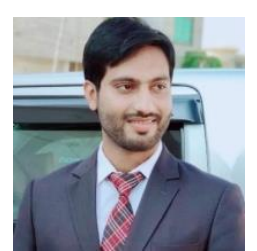

Mr. Fawad Sufyan has completed Msc (Hons.) in Soil Science from UAF. He is working in Better Cotton project since 2017. Mr. Fawad has expertise in data management and data analysis, and technical research skills and ability to conduct field trials. $\mathrm{He}$ has strong expertise in conducting hydroponic trails and development of materials, plans, layout and their implementation. He has also foreign exposure to visit Cambodia where he represented WWF-Pakistan in Better cotton project and won the award of "PU Manager of the Year".

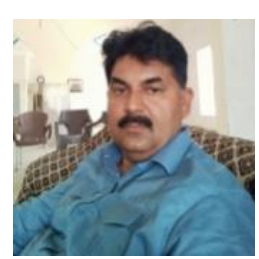

Mr. Imtiaz Hussain has completed Msc (Hons.) in Agronomy from Sindh Agriculture University, Tandojam. He is working asFocal Person of Sustainable Agriculture Farmers Welfare Organization, Sindh, since 2013. Mr. Burdi has expertise in crop management and crop productivity improvement, and ability to conduct research trials.

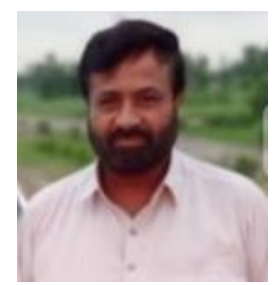

Mr. Fida Hussain Mangi has done his master's in agriculture from Sindh Agriculture University, Tandojam in 2000. Currently, he is working as Senior Cluster Coordinator at WWF- Pakistan office in Sukkur, Sindh. 